\title{
Map of Mineral Regulation Problems Related to the Miss Procedure and Violations of the Constitution in theMiddle of The Covid 19 Pandemic
}

\author{
Shanen Burgundy ${ }^{1},{ }^{*}$ Putri Lestari $^{2}$, Senia Putri ${ }^{3}$ \\ 1,2,3 Universitas Negeri Surabaya \\ "Corresponding author.Email: Shanen.19011@mhs.unesa.ac.id
}

\begin{abstract}
The Republic of Indonesia is a country that is rich in natural resources, from living natural resources to non-living natural resources. The potential of natural wealth starts from the sea, land, and other natural resources contained in the earth of Indonesia. Right on May 14, 2020, the mineral and coal mining Regulation was approved and create several pros and cons in the community as well as various problem maps. Mineral and coal mining regulation is a congressman's initiative that has been drafted since the 2014-2019 DPR period. Based on Article 71A of Law 15/2019, the carry-over discussion of the bill must complete the requirement that the previous period of the problem inventory list discussion has been carried out by the Congressman, whereas the Congressman's last period had not even once discussed the problem inventory list of the mineral and coal mining Bill. One of the line maps of the Minerba Regulatory problems certainly triggers quite a complicated reaction from the community. In total 143 (of a total 217) articles were amended, or about $80 \%$ of the total number of articles in Law Number 4 of 2009. In detail, there were 51 articles added, 83 articles were amended, and 9 articles were deleted. The Minerba Law has the potential to conflict with Article 33 of the 1945 Constitution, especially paragraph 3 which states that the earth, water, and natural resources contained therein are controlled by the State and used for the greatest prosperity of the Indonesian people
\end{abstract}

Keywords: Minerba, Regulation, DPR (Congressman)

\section{INTRODUCTION}

Indonesia is a country with abundant natural resources, ranging from biological natural resources to non-biological natural resources. The potential of natural wealth starts from the wealth of the sea, land, earth, and other natural resources contained in the earth of Indonesia. The wealth of these natural resources has partly been used to fulfill the needs of the Indonesian people and some are still in the formof untapped potential due to various limitations such as technological and economic capabilities. The potential of such huge natural resources should be able to contribute to the development of the country and also to the welfare of the people if managed properly by the government.

The wealth of natural resources itself includes agriculture, forestry, marine, fisheries, animal husbandry, plantations, as well as mining and energy. The wealth of energy and mineral resourcesin Indonesia cannot be separated from the geographical conditions and the position of Indonesia which is located in the world's volcanic belt. Not only as a support for life, energy and mineral resources are also one of the main sectors in nation-building. Indonesia has a great opportunity to become a country that has high energy sovereignty with energy and mineral resources 
scattered throughout the archipelago. Article 33 paragraph (3) of the 1945 Constitution of the Republic of Indonesia states that the earth, water, and natural resources contained therein are controlled by the state and used for the maximum benefit of the people. In the article, it is explained about the prohibition of control of certain individuals or groups of assets owned by the state.

The meaning of the word control here does not mean that the state becomes the ruler of all the natural wealth it owns, however, the power of the state lies in the authority of the state to make regulations as a smooth running of the economy, regulations that also prohibit the exploitation and oppression of the weak by people with capital.[1]

\section{METHODS}

The type of research in this research is normative juridical research. Normative juridical research is legal research that is pure and applied, normative juridical research is carried out by a legal researcher to examine a norm such as in the fields of justice, legal certainty, order, expediency, legal efficiency, legal authority, as well as norms and doctrines law, which underlies the application of these elements into the procedural and substantive legal field. In this normative juridical research, the problem approach used is the statutory approach. We correlate it with Article 33 of the 1945 Constitution. The Minerba Law has the potential to conflict with Article 33 of the 1945 Constitution, especially paragraph 3 which states that the earth, water, and natural resources contained therein are controlled by the State and used for the greatest prosperity of the people. Meanwhile, in the Minerba Law after the revision, this regulation has the potential to only benefit investors' prosperity. In Articles 169A and 169B holders of Contracts ofWork (KK) and holders of Coal Mining Work Agreements (PKP2B) will have the convenience of obtaining Business Permits. There is a definition of a Mining Legal Area that will encourage massive mining exploitation, not only inland areas but also in the sea which is contrary to the Coastal and Small Island Law. The carryover of the Minerba Bill to the DPR for the 2019-2024 period is illegal because it contradicts Article
71A of Law 15/2019. The absence of the role of the Regional Representatives Council (DPD) under Article 22D of the 1945 Constitution and the Decision of the Constitutional Court (MK) 92/PUU-X/2012. The discussion of the Minerba Bill must involve the DPD. This is based on Article 22D of the 1945 Constitution, Article 249 of Law 17/2014 concerning theMPR, DPR, DPD, and DPRD (MD3), as well

as MK Decision 92/PUU-X/2012. In the Constitutional Court Decision 92/PUU-X/2012it is stated that the DIM is proposed by the President and the DPD if the Bill comes from the DPR. There was no DIM made by the DPD during the discussion of the Minerba Bill. The absence of DIM from the DPD and the absence of DPD involvement in the preparation and discussion of this contradicts the mandate of Article 22D of the 1945 Constitution, Law No. 12/2011, and the Constitutional Court'sDecision. (Ahmad Redi. 2020).

The Sculpture Approach is an approach that is carried out by reviewing all laws and regulations related to the research to be carriedout. This legal approach will open up opportunities for researchers to study whether there is consistency and conformity between one law and another. Sources of data used in normative legal research are secondary data consisting of 3 (three) sources of legal materials, namely: a.) primary legal materials; b.) secondary legal materials; and c.) tertiary legal materials. The way of collecting data in this research is a literature study. Library Research is a way of collecting data by collecting relevant information based on the topic or problem that is the object of research. This information can be obtained from books, scientific works, theses, dissertations, encyclopedias, the internet, and other sources. Normative juridical research with secondary data types uses a qualitative approach, because normative legal research never gives the same results (repetitive), and the legal norms sought by legal research have a "definite" character, not a "probability" character. Meanwhile, analyzing legal materials is done through content analysis which is intended to describe the characteristics and interesting inferences of 
the content. As well as using descriptive writing techniques, to explain in detail and systematically the problem-solving.

\section{RESULTS AND DISSCUSSION}

\subsection{Illegal Mining Regulation}

On May 14, 2020, the Minerba Bill was ratified into the Minerba Law and turned off several pros and cons in society. The Minerba Bill is a DPR initiativebill that has been drafted since the 2014-2019 DPR period and until the last term of office of the DPR ended in September 2019, there was no discussion on the DIM. The Minerba Bill was then ratified in May 2020. Based on Article 71A of Law 15/2019, carry Over a discussion of the bill must meet the requirements that the DIM discussion has been carried out by the DPR in the previous period, eventhough the DPR in the previous period had not once discussed the DIM for the Minerba Bill.

The carryover of the Minerba Bill to the DPR for the 2019-2024 period is illegal because it contradicts Article 71A of Law 15/2019. The absence of the role of the Regional Representatives Council (DPD) following Article 22D of the 1945 Constitution andthe Decision of the Constitutional Court (MK) 92/PUU-X/2012. The discussion of the Minerba Bill must involve the DPD. This is based on Article 22D of the 1945 Constitution, Article 249 of Law 17/2014 concerning the MPR, DPR, DPD, and DPRD (MD3), as well as MK Decision 92/PUU- X/2012. In the Constitutional Court Decision 92/PUU-X/2012 it is stated that the DIM is proposed by the President and the DPD if the Bill comes from the DPR. There was no DIM made by the DPD during the discussion of the Minerba Bill. The absence of DIM from the DPD and the absence of DPD involvement in the preparation and discussion of this contradicts the mandate of Article 22D of the 1945 Constitution, Law No. 12/2011, and the Constitutional Court's Decision.[2]

\subsection{Contrary to the 1945 Constitution and exacerbate the economic crisis amid during in the Covid 19 Pandemic}

The regulation of mineral and coal mining has been amended several times until the most recent, namely through Law no. 4 of 2009 concerning Mineral andCoal Mining. This regulation has also undergone a revision process to the final stage. It is estimated that in the future this regulation will improve the management of Minerba in Indonesia, so that Indonesia can provide maximum benefits and welfare for the people. [3]

However, after several hours of ratification, this Minerba regulation has been the subject of much debate. As we know, during the COVID-19 pandemic, the House of Representatives (DPR) continues to ratify the revision of the Mineral and Coal Regulation (UU Minerba). A total of 143 (out of a total of 217) articles were changed, or about $80 \%$ of the number of articles in Law Number 4 the Year 2009. In detail, there are 51 articles added, 83 articles amended, and 9 articles deleted. The Minerba Law has the potential to conflict with Article 33 of the 1945 Constitution, especially paragraph 3 which states that the earth, water, and natural resources contained therein are controlled by the State and used for the greatest prosperity of the people. Meanwhile, in the Minerba Law after the revision, this regulation has the potential to only benefit investors' prosperity. In Article 169A and 169B holders of Contracts of Work (KK) and holders of Coal Mining Work Agreements (PKP2B)will have the convenience of obtaining Business Permits.

\subsection{Exploitation of Mine}

Special Mining (IUPK) and extension of IUPK without going through a potentially arbitrary auction process. Article 47 (a) states that the maximum period of metal mineral mining production operations is 20 years and is guaranteed to obtain two extensions of 10 years each after fulfilling the requirements following the laws and regulations. So that companies in PKP2B can "control" coal mines for up to two decades. Article 47 (a) states that the maximum period of metal mineral mining production operations is 20 years and is guaranteed to obtain two extensions of 10 years each after fulfilling the requirements by the laws and regulations. So that companies in PKP2B can "control" coal mines for up to two decades.

There is a definition of a Mining Legal Area that will encourage massive mining exploitation, notonly inland areas but also in the sea which is contrary to the Coastal and Small Island Law. There is a change in Article 100 which makes it possible 
for reclamation and post-mining not to be returned to the initial zone. Article 102 in the revision of the Minerba Law also eliminates the obligation of coal entrepreneurs to downstream and provides all fiscaland non-fiscal incentives for the mining and coal industry. Article 93 allows IUP \& IUPK to be transferred with the permission of the minister.

\subsection{Injuring the mandate of the 1945 Constitution (UUD NRI 1954)}

The capacity of the central government in fostering and supervising mining is doubted by the public. The mandate of the ideals of the 1945 Constitution and the Proclamation of August 17, 1945, aims to create a just and prosperous society, in which Article 33 of the 1945 Constitution states that the Earth, water, and natural resources contained therein are controlled by the State and used for the greatest prosperity of the people [4]. This article clearly explains that the Prohibition of Ownership of Natural Resources on an individual basis or the monopoly of private companies, especially foreign companies. This is where the government's important function is to protect the country and the people of Indonesia. Therefore, the Mining Law is invalid if in its implementation it is proven to be contrary to the principles of Article 33 of the 1945 Constitution.[5]

\subsection{Restricting the right to regional autonomy}

Regarding the control of minerals and coal, the government and the DPR agree that the control of minerals and coal is carried out by the central government through the functions of policy, regulation, administration, management, and supervision. In addition, the central government has the authority to determine the amount of production, sales, and prices of metallic minerals, certain types of non-metallic minerals, and coal. This regulation has clearly violated the constitutional right to exercise the widest possible autonomy, except for government affairs which are determined by law to be the affairs of the central government as referred to in Article 18 paragraph (5) of the 1945 Constitution that "Regional governments exercise the widest possible autonomy, except government which by law is determined as the affairs of the central government.
Utilization of natural resources and other resources in a fair and harmonious manner based on the Law as referred to in Article 18A paragraph (2) of the 1945 Constitution that "Financial relations, public services, utilization of natural resources and other resources between the central government and regional governments are regulated and implemented fairly and in harmony based on the law."

A public legal entity and a government in the narrowsense (bestuur) is constitutionally entitled to control the production branches of mineral and coal mining which are important for the state and the prosperity of the people as referred to in Article 33 paragraph (2) the 1945 Constitution that "Production branches which are important for the state and which affect the livelihood of the people are controlled by the state" and Article 33 paragraph (3) of the 1945 Constitution, namely "Earth and water and the natural resources contained therein shall be controlled by the State and used for the greatest prosperity of the people.

Mining activities that are popular nowadays are mining activities for metal mineral commodities, including gold, copper, nickel, bauxite, and coal commodities. Although it should be, in addition to the importance of minerals and coal as the main commodities in mining, rock commodities also have an equally important role, especially in providing material support for infrastructure development, including the establishment of road infrastructure facilities, construction of housing and office buildings.

Mining Business Permit (IUP) is a permit to carry out mining activities. as described in Article 1 Point 7 in Law no. 4 of 2009 concerning Mineral and CoalMining. In the process, the granting of Mining Business Permits becomes the authority of the Central Government and the Provincial Government. This is as mandated by Law No. 23 of 2014 concerning Regional Government which explains that the authority for mining, electricity, renewable energy, and geology is divided between the central government and the provincial government by taking into account the Principles of Accountability, Efficiency, and Externalities, as well as National Strategic Interest. However, the revision of the Minerba Law provides an opportunity for IUP holders to have more than one 
IUP [6]. This is explained in Article 40 paragraph 1a of the Revised Law. so that later it will provide an opportunity for IUP holders to cultivate other mining commodities other than the main mine that is being exploited thus of course it will cause the emergence of potential natural damage that is as large as a corporate scale, Mining will be carried out without limits, this returns mining management to the principle of "selling cheap dredge up". Theexisting provisions in the revision of the Mining Law are of course clearly worse than those contained in Act No.4 of 2009.

\subsection{Weakening the position of State}

Pursuant to Article 33 paragraph (2) of the Law of the Republic of Indonesia Year 1945 states that branches of production important for the State and which control the livelihood of the people are objects that have the nature of public interest. Thus, there is no ownership right by anyone because the object is a public good that must be accessible and used by anyone. Therefore, the management and utilization of these public goods need to be controlled by the government in the form of a Public Permit, so that the public can access them. So that the State as the ruler of natural resources has an important role to manage the existing potential and fully utilized it for the interests and welfare of the people. However, the revision of the Minerba Law actually weakens the position of the state because the mechanism used is a "contract" period, not a permit. In fact, what is mandated in Article 33 of the 1945 Constitution should be very clear where the earth and water and the natural resources contained therein are controlled by the state and used for the greatest prosperity of the people.

\subsection{Limiting people's voices}

But now the manifestation of people's prosperity seems to be injured or even eliminated. People are not given the veto power to refuse. People like indigenous peoples should have the right to say "no" to mining business permits in their territory because the Minerba Law Revision does not at all narrow the space for dredging expansion in mining activities, but instead becomes an accelerator of natural resource dredging. Although there is an article that reads about the consideration of human rights (HAM) instruments.
National development that pursues macroeconomic growth by expanding industrial areas will accelerate the dredging of natural resources to support the growth and expansion of industrial areas. This will have the potential to criminalize people who reject natural resources in order to support the growth andexpansion of industrial estates. This will have the potential to criminalize people who refuse.

\subsection{Mining regulations are not transparent}

The discussion of the Minerba Bill, which wasdrafted in the DPR from the start, is not transparent. Then, community participation is also very minimal so that most of the contents of the bill accommodatethe interests of business actors. In the mining sector, it is very important to accommodate the interests of the working area community, such as pollution and environmental damage, and land security. The views of the factions seemed to be just a formality because the notes of each faction during the level I discussions were not discussed in the ratification meeting. There is one party's view that asks Article 165 of the Minerba Law not to be abolished but there is no further discussion on this matter. Not to mention the notes on other articles. This means that a number of factions admit that there are many problematic articles, but they are not discussed and instead agree. (Aryanto Nugroho: 2020)

The law is an important instrument and a legal policy in the administration of a government system in order to achieve state goals. So the law should provide protection and enforcement of human rights. Legislation is dependent on a political process where politics is unpredictable. This dynamic nature of politics often causes the discussion of laws to drag on and is often stopped due to changes in legislative positions. The change of position is considered as a renewal of aspirations to accommodate the people's voice to the new people's representatives.

However, the change of office also caused delays and even termination of the discussion of the bill in the previous period. This can be detrimental to the community because the APBN that has been used for the discussion of the previous bill is not used efficiently. As a result, there is an urgency to ensurethe continuity of the discussion of the bill in the previous period in order to provide protection and enforcement of human rights as well as the efficient 
use of the APBN. The urgency is based on the principles of good governance, effectiveness, efficiency, and protection of human rights.

Article 71A of Law 15/2019 has accommodated the implementation of the system carry over in the process of forming laws and regulations. In Indonesian, the term carryover means "to continue"or "to pass". If interpreted means the inheritance of the bill from the old period to the new period.

\subsection{Violations of the law, violations of the constitution, and violations of the code of ethics}

Discussions on the revision of the mineral and coallaw occurred during the 2014-2019 period of government. Since the beginning of the discussion of this bill, the DPR did not involve the DPD and took place behind closed doors. If the DPR and the Government continue to make decisions on the Minerba Law Revision, these two institutions have clearly violated the law, violated the constitution, and violated ethics (Executive Director of the Center of Energy and Resources Indonesia, Yusri Usman). This is because the entire discussion of the Minerba Law Revision by the DPR and the Government is carried out in a closed manner and isnot carried out in the DPR Building and does not involve public participation. DPD should be involved in the discussion of this bill because this bill relates to the authority of natural resources, central authority, and regional authority. In Article 71A of Law 15/2019, it is stated that the carryover of the discussion of the Bill must meet the requirements that the DIM discussion has been carried out by the previous period's DPR, even though the DPR in the previous period had not once discussed the DIM of the Minerba Bill.

The DPD's not being involved in discussing this bill is certainly not in accordance with Article 22D of the 1945 Constitution, which is that it can submit a bill to the DPR, the DPD will participate in discussing the bill and giving consideration to the DPR. In the case of submitting a bill, in addition to the provisions contained in the 1945 Constitution, other provisions are also briefly regulated in Law no. 22 of 2003 that the DPD proposes a draft law for matters that have been mentioned in the 1945 Constitution to the DPR and the DPR invites the DPD to discuss it in accordance with the DPR's rules and regulations.
The discussion of the draft law is carried out before the DPR discusses the draft law with the government. The law stipulates that bills, whether from the DPR, the President, or from the DPD, are drawn up based on the National LegislationProgram. By not involving the DPD in thediscussion of the Minerba Bill, the DPR has violated Article 6 of DPR RI Regulation No. 1 of 2014 concerning the Code of Conduct. Article 6 letter $\mathrm{C}$ states that the DPR has the authority to discuss draft laws proposed by the President or the DPR relatingto regional autonomy, central and regional relations, formation and expansion as well as regional mergers, management of natural resources and other economic resources, and balance of central and regional finances, by involving the DPD before jointapproval is taken between the DPR and the President.

Article 5 of Law no. 12 of 2011 contains the principles for the formation of laws and regulations. One of the principles listed is openness. The discussion of the bill which is closed to the public and does not involve the DPD and even access to view the draft bill which is difficult is certainly not in accordance with the meaning of the principle of openness. The draft law must also be based on the aspirations and needs of the community as stated inArticle 18 of Law no. 12 of 2011 [7]. Article 21 also states that the preparation of the National Legislation Program is carried out by the DPR and the Government with coordination and consideration from factions, commissions for members of the DPR, DPD, and/or the community.

\section{CONCLUSION}

The Republic of Indonesia is a country with abundant natural resources, ranging from living natural resources to non-biological natural resources. The potential of natural wealth starts from the wealth of the sea, land, earth, and other natural resources contained in the earth of Indonesia. The wealth of natural resources has partly been used to fulfill the nation's livelihood. The wealth of natural resources itself includes agriculture, forestry, marine, fisheries, animal husbandry, plantations, as well as mining and energy. The wealth of energy and mineral resources in Indonesia cannot be separated from the geographical conditions and the position of 
Indonesia which is located in the world's volcanic belt.

The Minerba Bill is a DPR initiative bill that has been drafted since the 2014-2019 DPR period and until the last term of office of the DPR ended in September 2019, there was no discussion on the DIM. This regulation has violated the constitutional right to exercise the widest possible autonomy, except for government affairs which are determined by law to be the affairs of the central government as referred to in Article 18 paragraph (5) of the 1945 Constitution that "Regional governments exercise the widest possible autonomy, except government which by law is determined as the affairs of the central government.

The problem doesn't just stop there. The Minerba regulation is considered illegal. After all, it is clear that the carry-over of the Mineral and Coal Bill to the DPR for the 2019-2024 period is illegal because it contradicts Article 71A of Law 15/2019. The absence of the role of the Regional Representatives Council (DPD) by Article 22D of the 1945 Constitution and the Decision of the Constitutional Court (MK) 92/PUU-X/2012. The discussion of the Minerba Bill must involve the DPD. After the revision of the Minerba Law, it is also suspected that this regulation will potentially only benefit investors' prosperity. Injuring the Constitution, exploiting mines, restricting people's voices, violating the law and code of ethics.

This series of problem maps are a form of accuracyfrom the public in observing legal loopholes that canbe caused by the Minerba Regulation. The government should make regulations that arepeaceful and run in the proper corridors of law and constitution. So that despite the complexity of the problems of the Covid-19 pandemic, we can quickly be free and rise towards a better Indonesia.

\section{REFERENCES}

[1] V. Nalle, "Hak Menguasai Negara Atas Mineral Dan Batubara Pasca Berlakunya Undang-Undang Minerba," J. Konstitusi, vol. 9, no. 3, pp. 473-494, 2012.
[2] Bphn, "Undang-Ungan No 12 Tahun2011 Tentang Pembentukan Peraturan Peundang -Undangan," p. hlm. 39-41, 2011, [Online]. Available:

http://bphn.go.id/data/documents/11uu012.pdf.

[3] Pemerintah RI, "Undang Undang Pertambangan Mineral Dan Batubara," UuNo 4 Tahun 2009 Tentang Pertamb. Dan Batubara, p. 4, 2009.

[4] UUD, “UUD NR1 1945," vol. 105, no. 3, pp. 129-133, 1945, [Online]. Available: https://webcache.googleusercontent.com/se arch?q=cache:BDsuQOHoCi4J:https://medi a.neliti.com/media/publications/9138-IDperlindungan-hukum-terhadap-anak-darikonten-berbahaya-dalam-media-cetak-danele.pdf $+\& \mathrm{~cd}=3 \& \mathrm{hl}=\mathrm{id} \& \mathrm{ct}=\mathrm{clnk} \& \mathrm{gl}=\mathrm{id}$.

[5] A. S. Yuking, "Kepastian Hukum dalam Undang-Undang Minerba," Law Rev., vol. Volume XI, no. Nomor 1 Juli, p. hlm.45., 2011.

[6] F. Widyansari, "UU NO 23 TAHUN2014," Modal Sos. Dalam Pendidik. Berkualitas Di Sekol. Dasar Muhammadiyyah Muitihan, no. September, 2014.

[7] undang-undang republik indonesia, "Law of the Republic of Indonesia No. 22 of 2003 on the Composition and Position of the People's Consultative Assembly, the House of Representatives, the Regional House of Representatives, and the Regional House of Representatives," 2003. 